\title{
PENERAPAN TIPOLOGI KANTOR, ARSITEKTUR DAN PERILAKU MILENIAL PADA PERANCANGAN STUDIO ANTAR-KREATIF DI TEBET
}

\author{
Kristel Karina Lestari ${ }^{1}$ \\ ${ }^{1}$ Program Studi S1 Arsitektur, Fakultas Teknik, Universitas Tarumanagara, kristelkarinaa@gmail.com
}

\begin{abstract}
Abstrak
Kemajuan teknologi telah mempermudah pekerjaan, baik secara langsung maupun tidak langsung. Hal ini telah merubah gaya hidup masyarakat, khususnya generasi millenial di Jakarta. Tidak sedikit generasi milenial berpindah - pindah pekerjaan, yang tidak menutup kemungkinan bahwa generasi milenial berjalan sesuai dengan kebutuhan masing - masing. Generasi millenial mendefinisikan keseimbangan sebagai salah satu hal yang dilihat dalam menjalani kehidupan. Studio Antar - Kreatif merupakan sebuah wadah yang menyediakan ruang bekerja menjadi lebih interaktif, kreatif dan fleksibel dalam bidang ekonomi kreatif di sub-sektor multimedia untuk meningkatkan kreativitas dan perekonomian. Studio Antar Kreatif didesain dengan tujuan menyediakan wadah bekerja mandiri bagi generasi milenial dengan memperhatikan keseimbangan hidup kaum pekerja. Melalui trans-programming yang memadukan program bekerja kreatif dan hiburan sebagai satu kesatuan didalam sebuah desain menciptakan sebuah ruang yang sama dengan intensitas waktu penggunaan yang bergantian. Adanya konsep fasad memberikan ekspresi terhadap arsitektur dengan kombinasi melodi dan ritme serta konsep perbedaan ketinggian lantai dalam desain sebagai gambaran kreativitas dan spasialitas ruang dalam arsitektur dengan pencahayaan, material hingga bentuk.
\end{abstract}

Kata Kunci: fasilitas bekerja; fasilitas hiburan; milenial bekerja; studio kreatif; transprogramming

\begin{abstract}
Technologicaly advancements have facilitated work, both directly and indirectly. This has changed the lifestyle of the people, especially the millennial generation in Jakarta. Not a few generations often changing jobs, which are not closed in the current generation according to their individual needs. Millennial generation approved balance as one of the things seen in the agreement of life. Inter-Creative Studio is a space that provides a more interactive, creative and flexible work space in the creative economy in the multimedia sub-sector to enhance creativity and economy. Inter-Creative Studio is designed with the aim of providing a place to work independently for the millennial generation by paying attention to the life balance of workers. Through trans-programming that combines creative work and entertainment programs as a whole in the design creates the same space with the integration of changing usage times. The existence of the facade concept gives expression to architecture with a combination of melody and rhythm and the concept of height differences in design as creativity and spatial space in architecture with lighting, materials to building form.
\end{abstract}

Keywords: creative studio; entertainment facilities; millennials work; transprogramming; work facilities.

\section{PENDAHULUAN}

Generasi $Y$ atau generasi milenial merupakan generasi yang mayoritas tengah berada di zaman ini. Generasi $Y$ terbentuk dari berkembangnya ilmu teknologi dan informasi sehingga 
generasi ini akan memberikan celah untuk bekerja dan memenuhi kebutuhan hidup yang akan datang.

Tingkat kesuksesan dimasa dewasa dan masa tua ditentukan oleh pekerjaan, selain pendidikan yang diterima di masa muda. Wirausaha saat ini juga menjadi alternatif kalangan muda dalam berkarya, start-up bisnis bermunculan di berbagai kota. Tidak sedikit generasi milenial di Indonesia berpindah - pindah pekerjaan dikarenakan pola pikir dan gaya bekerja generasi $Y$ yang berbeda dari generasi sebelumnya, dimana hirarki menjadi lebih lentur dan fleksibilitas pada ruang dan waktu.
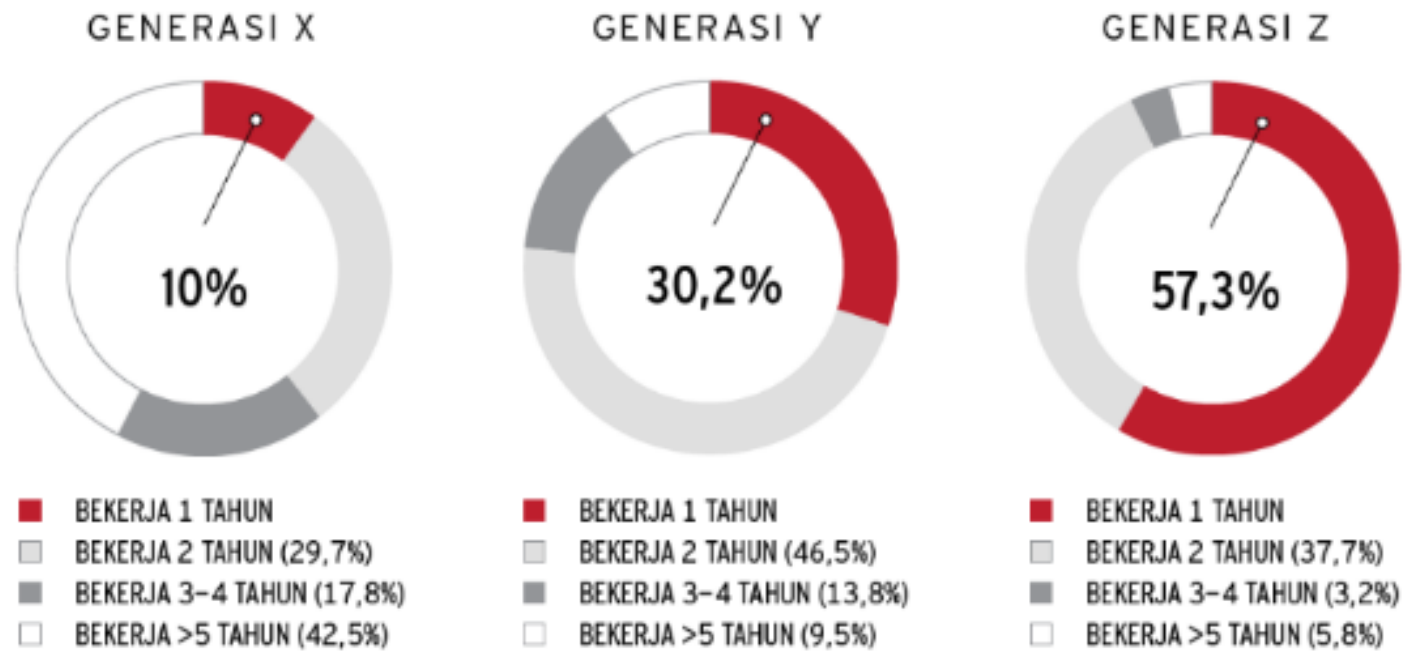

Gambar 1. Survei Tingkat Kesetiaan Karyawan Berdasarkan Generasi

Sumber: Jobplanet.com oleh Aprilianti, 2018

Generasi milenial mendefinisikan keseimbangan sebagai salah satu hal yang dilihat dalam menjalani kehidupan, terkait orientasi tujuan dan pekerjaan. Diperlukannya sebuah ruang yang dapat mewadahi aktivitas bekerja milenial secara kreatif dan mandiri yang memperhatikan kesejamanan dan kebutuhan generasi milenial. Hiburan merupakan salah satu bentuk aktivitas untuk bersosialisasi dan menikmati waktu di samping bekerja sebagai kegiatan yang dapat menghilangkan kejenuhan dan membantu mengembalikan kondisi produktivitas bekerja.

Usulan program "Studio Inter - Creative" merupakan jawaban atas isu tersebut, dengan memadukan kebutuhan dan keseimbangan hidup milenial dalam bekerja sebagai bentuk fleksibilitas dan kreativitas yang berorientasi terhadap nilai kesejamanan.

\section{KAJIAN LITERATUR}

\section{Generasi Milenial}

Milenial adalah kelompok demografi Generasi Y, Generasi X dan setelahnya. Para ahli dan peneliti biasanya menggunakan awal 1980-an sebagai awal kelahiran kelompok ini dan pertengahan tahun 1990-an hingga awal 2000-an sebagai akhir kelahiran.

Berdasarkan Ali dan Purwandi L (2016) dalam buku Indonesia 2020: The Urban Middle Class Millenials, generasi milenial adalah generasi yang akan membentuk kembali cara bekerja, berkomunikasi (bergaul), cara bertahan hidup hari-harinya. Secara global, generasi ini adalah generasi terbesar, walaupun ukuran relatifnya sangat bervariasi. Generasi milennial merupakan generasi yang mencari identitas dan hal baru untuk memahami peristiwa dan gagasan di dunia di sekitar mereka.

Umumnya sifat generasi millennial yang menonjol berada pada generasi $Y$, dikarenakan mereka mengalami sebuah kejadian dimana pengembangan teknologi sedang maju dengan pesat. 


\section{Kantor Bagi Kaum Pekerja Milenial}

Secara etimologis, kantor berasal dari bahasa Belanda yaitu Kantoor yang artinya ruangan tempat bekerja, tempat instansi dan lain-lain. Lalu jika dalam bahasa Inggris berasal dari kata Office yang artinya tempat untuk memberikan pelayanan, ruang tempat bekerja ataupun posisi. Berikut ini merupakan sejarah berkembangnya kantor:

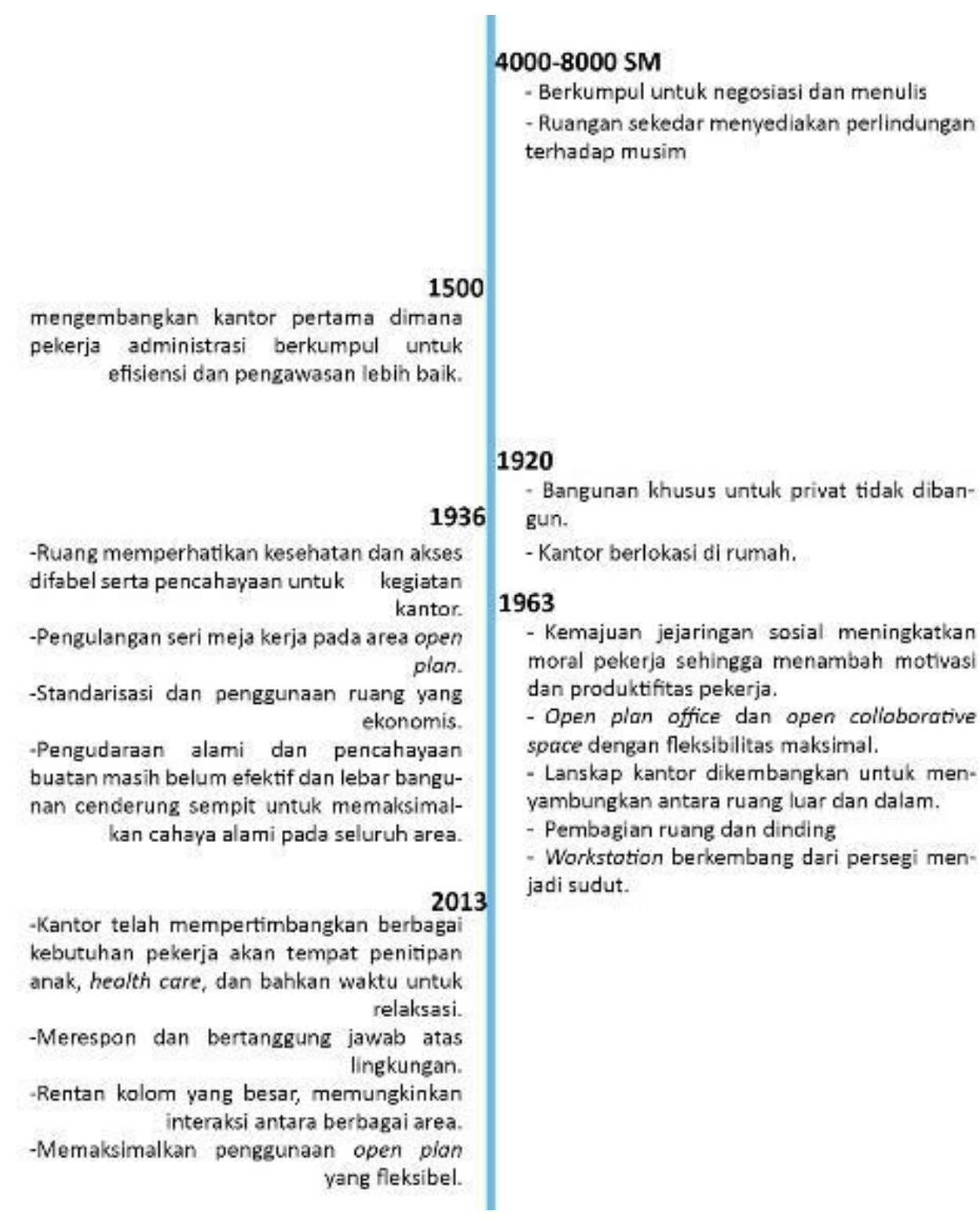

Gambar 2. Perkembangan Kantor

Sumber: Ditulis ulang oleh penulis berdasarkan Jaya: AR. 3131 , 2019

\section{Fasilitas Hiburan Untuk Kaum Pekerja}

Hiburan adalah segala sesuatu baik yang berbentuk kata, tempat, benda, perilaku yang dapat menjadi penghibur atau pelipur hati yang susah atau sedih. Fasilitas hiburan untuk kaum pekerja mengacu pada saat malam hari. Menurut R.S. Darmajati, (2005:25) tempat hiburan malam berasal dari kata tempat yang berarti suatu area/tempat atau lokasi dan hiburan memiliki persamaan arti kata entertainment dalam bahasa inggris yang berarti sejenis tourist attraction / wisatawan. Kata malam memiliki kecenderungan untuk menunjukkan waktu yaitu malam hari. 
Dapat disimpulkan tempat hiburan malam merupakan tempat dengan jenis kegitan berupa pertunjukan, keramaian dan permainan dengan tujuan untuk menghibur dan memberikan kepuasan rohani sesuai dengan keinginan pengunjung yang cenderung dilakukan pada waktu malam hari. Ada beberapa macam tempat hiburan malam sebagai berikut:

\begin{tabular}{c|c|c|c|c|c|} 
Discotheque & $\begin{array}{l}\text { tempat hiburan dimana pengunjung dapat menari disuatu ruangan } \\
\text { diiringi lagu-lagu disco. }\end{array}$ \\
Cocktail Lounge & $\begin{array}{l}\text { sebuah tempat baik diluar maupun didalam ruangan yang } \\
\text { diorganisasikan secara komersil, dimana disajikan minuman dan } \\
\text { makanan dengan pelayanan prima, dekorasi mewah serta diringi } \\
\text { musik/ hiburan. }\end{array}$ \\
Karaoke & $\begin{array}{l}\text { biasa disebut juga Lounge Bar tempat luas memanjang dengan } \\
\text { lingkungan lebih nyaman daripada bar biasa. } \\
\text { tempat hiburan yang disediakan untuk bernyanyi atau melatih hobi } \\
\text { menyanyi. }\end{array}$ \\
$\begin{array}{c}\text { tempat dimana pengunjung dihibur lewat lagu-lagu yang diringi suatu } \\
\text { kelompok band sambil menikmati minuman yang tersedia. } \\
\text { tempat dimana pengunjung dapat menikmati hidangan seperti sebuah } \\
\text { restoran yang dilengkapi dengan iringan musik untuk mengiringi tamu } \\
\text { yang tengah makan dan minum. }\end{array}$
\end{tabular}

Gambar 3. Jenis Tempat Hiburan Malam

Sumber: H.Marsum, 2004

\section{Musik dan Arsitektur}

Dalam Kamus Besar Bahasa Indonesia (1995: 676) mengatakan bahwa musik adalah nada atau suara yang disusun sedemikian rupa sehingga mengandung irama, lagu dan harmoni. Musik merupakan rangkaian unsur - unsur harmoni yang tergabung menjadi satu sehingga membentuk suatu melodi berupa lagu. Arsitektur merupakan ilmu merancang bangunan dalam skala mikro maupun makro. Keterkaitan musik dengan desain dalam arsitektur menjadi salah satu fenomena alam yang menunjukan bahwa desain merupakan harmoni. Dimensi musik yang memiliki dua ruang dalam waktu yaitu nada dan sunyi sama hal nya dengan arsitektur yang memiliki ruang nyata dalam solid dan void. Berikut merupakan diagram yang menginterpretasikan hubungan antara musik dan arsitektur menurut Don Fedorko:

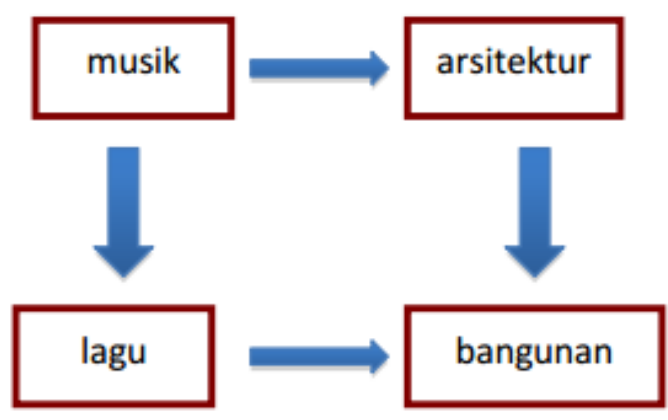

Gambar 4. Diagram Hubungan Musik dan Arsitektur Sumber: Antoniades, 1990 
Transformasi musik dalam arsitektur tergambar dari ilustrator dan arsitek asal Italia, Federico Babina yang mewujudkan keterkaitan musik dan aristektur berjudul Archimusic. la menyatakan adanya cosmic connection yaitu musik dapat diwujudkan dalam dimensi ruang arsitektur yang berkaitan dengan garis budaya. Warna, irama, harmoni dan nuansa musik berbeda dapat membentuk arsitektur yang berbeda juga (Purwantiasning, Ari Widyati \& Djuha, Ahmad Mubarak, 2016).

\section{Musik dan Bekerja}

Musik dapat membantu individu untuk mengatasi berbagai gangguan klinis hingga untuk memperbaiki kondisi kehidupan seperti komunikasi serta meningkatkan berbagai kemampuan seperti kreativitas, konsentrasi dan pola pikir positif (Satiadarma, 2002). Musik dapat membantu otak berfokus pada hal yang dipelajari. Musik memberikan efek terhadap individu dalam hal produktifitas bekerja. Tempo memberikan efek semangat tersendiri. Ritme merupakan salah satu struktur dari musik. Ritme merupakan repetisi dari pola suara. Ritme dapat merangsang pola penting pertumbuhan otak (Davies, 2000). Ahli musik dan asisten di Departemen Musikologi di The University of Ghent, berpendapat bahwa 'tempo yang disukai' sekitar $120 \mathrm{bpm}$ adalah bagian dari biologi kita.

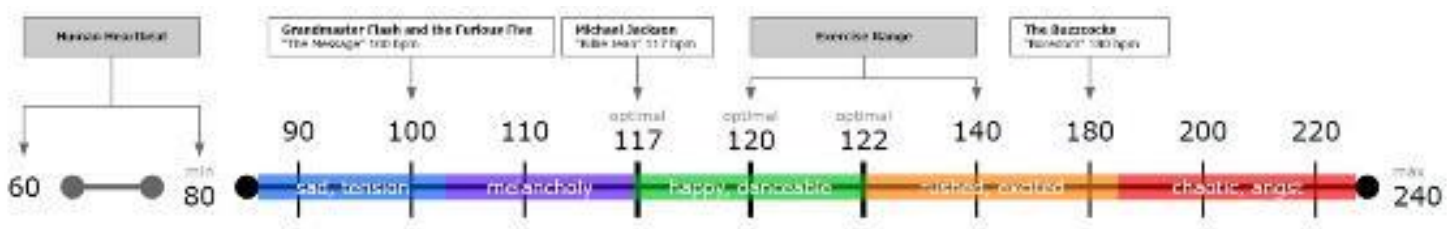

Gambar 5. Emotional BPM Assignment Diagram

Sumber: Blakke, 2014

\section{METODE}

Metode analisis dilakukan dengan mengolah data terhadap domisili milenial di Kota Jakarta sebagai acuan penentu kawasan dan analisis data berdasarkan hasil kuisioner mengenai gaya bekerja milenial dalam menentukan kebutuhan program yang sesuai. Setelah itu dilanjutkan analisis makro untuk melihat kriteria lokasi dengan aktivitas perkantoran dan hiburan yang tinggi. Tebet merupakan tempat dengan tingkat produktivitas dan aktivitas bekerja yang sesuai dengan kriteria lokasi. Setelah itu, dilakukan analisis mikro berdasarkan analisis lingkungan sekitar.

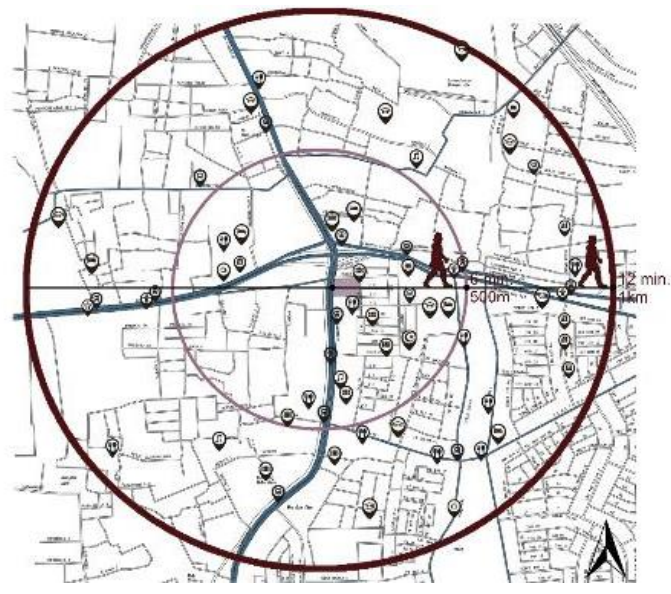

Gambar 6. Makro Analisis Tebet, Jakarta Selatan Sumber: Penulis, 2019 


\section{Metode Tipologi}

Metode tipologi digunakan untuk mengidentifikasi dan menganalisa lebih mengenai kantor yang menggambarkan klasifikasi dalam arsitektur berdasarkan bentuk dan fungsi. Pendekatan tipologi dari kantor yang berdasarkan perkembangannya dapat dijabarkan melalui gambar berikut:

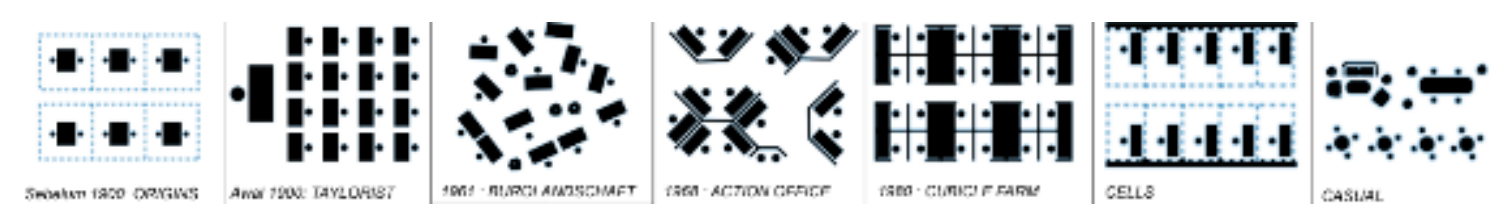

Gambar 7. Tipologi Kantor Berdasarkan Perkembangannya

Sumber: Liu, 2012

Berdasarkan dari zoning secara vertikal, umumnya kantor memiliki zona publik pada lantai bawah dan zona privat pada lantai atas. Seiiring berkembangnya waktu, generasi milenial menggeser kekakuan zona secara vertikal. Zona saling terintegrasi baik horizontal maupun vertikal.

\section{Dekonstruksi Ruang Kreatif Dalam Arsitektur}

Metode perancangan desain menggunakan pendekatan metode dari Bernard Tschumi (2005). Bernard Tschumi membedakan menjadi tiga konsep yakni: Cross-programming, Transprogramming, Dis-programming. Pendekatan Trans-programming digunakan untuk mengkombinasikan dua program dengan sifat dan konfigurasi spasial yang berbeda tanpa melihat kecocokannya.

\section{Arsitektur dan Perilaku}

Pendekatan ini merupakan studi tentang upaya mensintesis perilaku ke dalam arsitektur dari Behaviorology oleh Atelier Bow - Wow. Profesor Yoshiharu Tsukamoto (1965) mendefinisikannya sebagai teori arsitektur yang terkait erat dengan perilaku alam dan manusia. Aspek perilaku yang berulang, berirama, dapat dibagikan dan menggeser desain arsitektur dari individualistis ke basis kesamaan untuk membangun hubungan baru dengan masyarakat dan budaya.

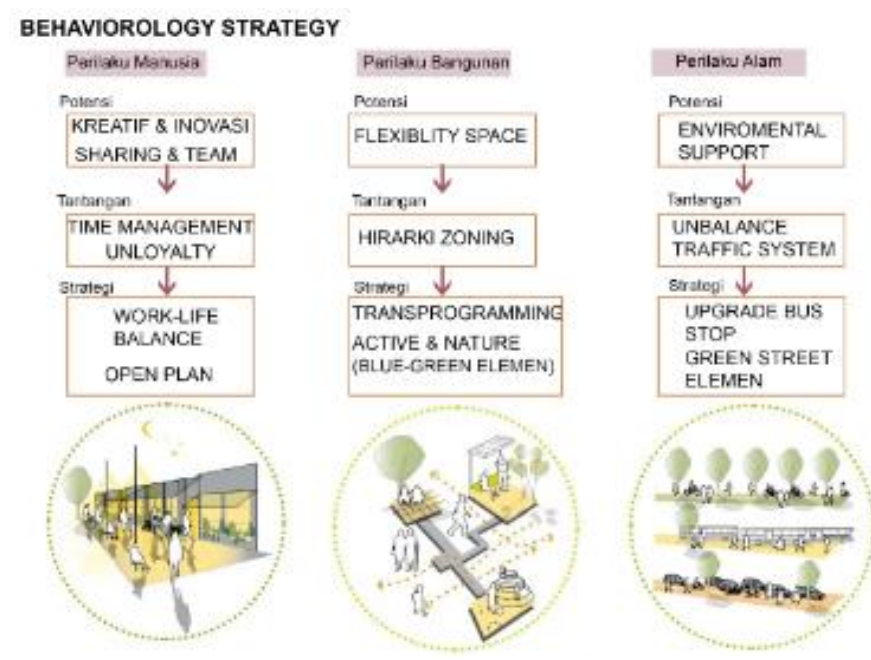

Gambar 8. Strategi Behaviorology

Sumber: Penulis, 2019 


\section{Metode Arsitektur dan Musik Sebagai Transformasi}

Don Fedorko (Antoniades,1990:274) mengembangkan teori arsitektur dengan menggunakan musik sebagai pendekatan dan sumber inspirasi dalam perancangannya. Musik merupakan suatu wujud atau cara berarsitektur dengan hasil dari kegiatan itu adalah lagu dan bangunan fisik. Arsitektur dapat dibaca sebagai musik karena didalamnya terdapat konsep musik yang mengaitkan kedua hal tersebut. Musik dimasukan melalui sebuah transformasi yang terwujud pada fasad bangunan sebagai salah satu saluran kreativitas arsitektural sebagai produk dari era Postmodernisme.

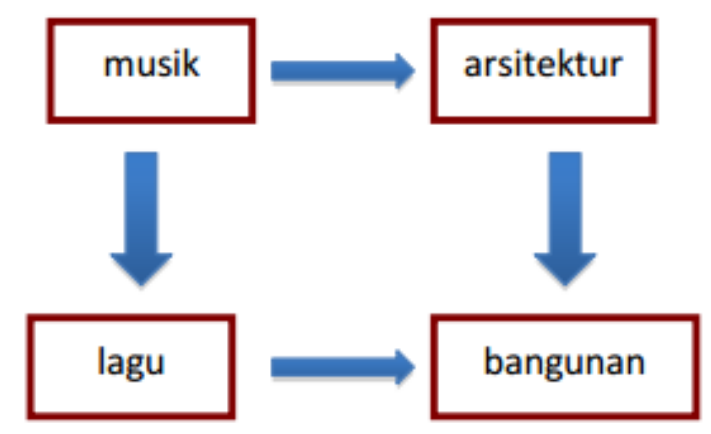

Gambar 9. Diagram Hubungan Musik dan Arsitektur Sumber: Antoniades, 1990

\section{DISKUSI DAN HASIL}

Setelah melakukan diskusi dan hasil, dilakukan pembaharuan desain kantor berdasarkan tipologi dengan memadukan program bekerja dan hiburan yang menyesuaikan dengan kebutuhan milenial. Desain total luas bangunan mencapai $\pm 12.480 \mathrm{~m}^{2}$ dengan program utama yaitu kantor kreatif (50\%), program hiburan (30\%) dan $20 \%$ untuk fasilitas pendukung yang terintegrasi pada zona vertikal dan horizontal.

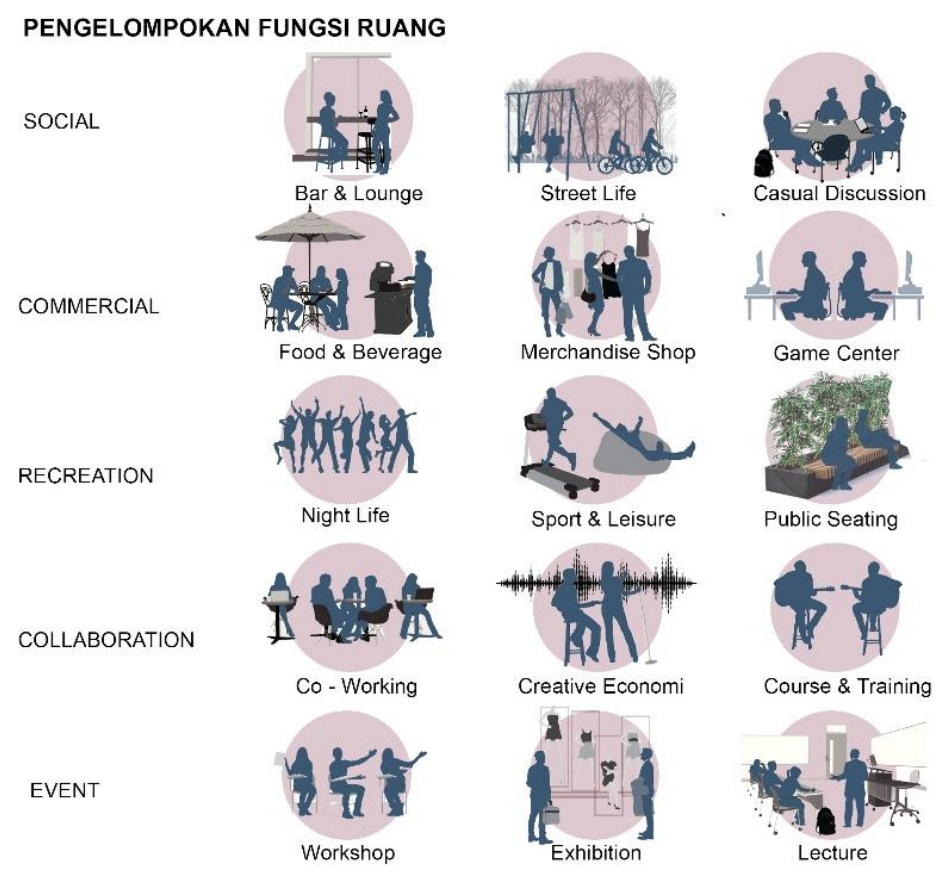

Gambar 10. Diagram Fungsi dan Aktivitas

Sumber: Penulis, 2019 
Dengan pendekatan dari teori dan metode yang digunakan maka terciptalah sebuah penggunaan ruang yang menggambarkan transprogramming area yaitu ballroom. Dengan intensitas ruang dapat memberikan kehidupan 24 jam bangunan untuk beroperasi sehingga dapat memberikan pelayanan sesuai dengan kebutuhan milenial masing - masing.

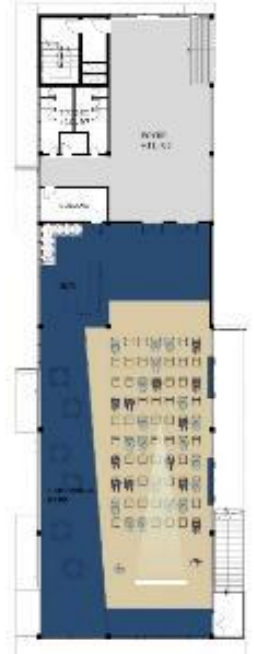

LECTURING

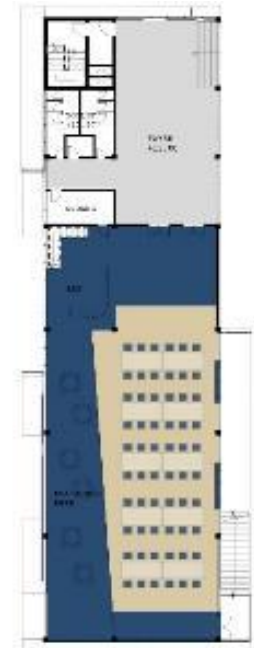

DINING

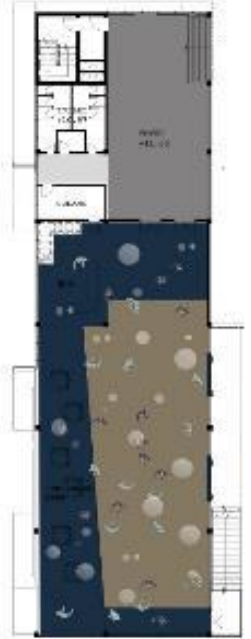

PARTYING

Gambar 11. Area Transprogramming Ballroom Sumber: Penulis, 2019

Dalam lingkungan kerja, milenial khususnya di Jakarta lebih senang melakukan dan menyelesaikan pekerjaan yang dianggap lebih efisien dalam waktu dan energi agar kejenuhan terasa seimbang yang mendukung nilai sosial. Dan untuk meningkatkan produktifitas, mereka cenderung mendengarkan musik atau menonton film. Pemahaman tentang hirarki kebutuhan manusia makin mendalam dengan penyempurnaan sehingga menciptakan sebuah rangkaian motivasi.

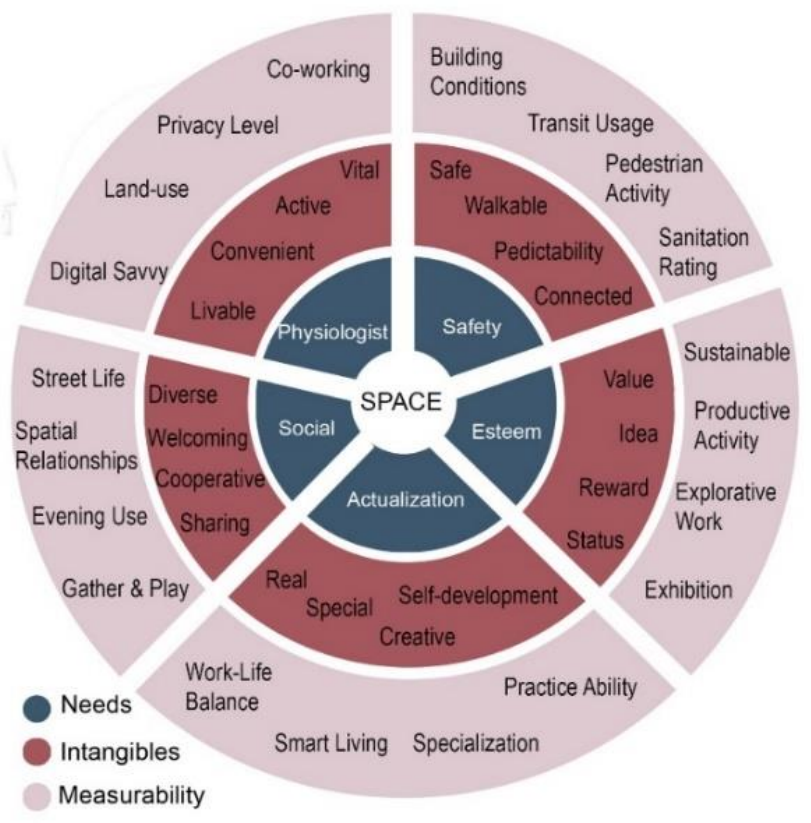

Gambar 12. Rangkaian Teori Maslow

Sumber: Penulis, 2019 
Produktifitas bekerja terkait dengan musik sebagai alat merangsang kreatifitas diwujudkan ke dalam fasad bangunan. Musik dengan tempo rata - rata $120 \mathrm{bpm}$ memberikan tingkat produktifitas dalam bekerja menjadi lebih kreatif dan meningkat. Sehingga pemilihan lagu kekinian yang mengacu pada tempo $120 \mathrm{bpm}$ adalah "New Light" dari John Mayer dengan kunci Mayor. Dilihat dari polanya, lagu ini memiliki pola yang berulang dan intonasi yang naik dan turun. Sehingga proses naik dan turun melodi lagu terekam menjadi sebuah alur dengan pola pengulangan yang di terapkan sebagai fasad bangunan.

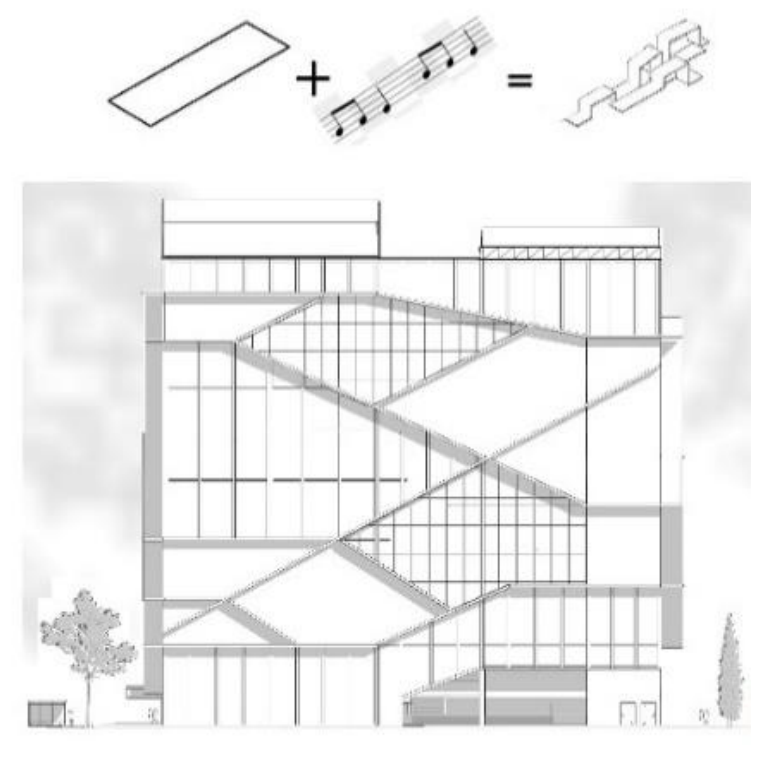

Gambar 13. Musik Sebagai Desain Fasad Sumber: Penulis, 2019

Berikut ini merupakan suasana ruang yang dihasilkan dari desain eksterior dan interior bangunan:

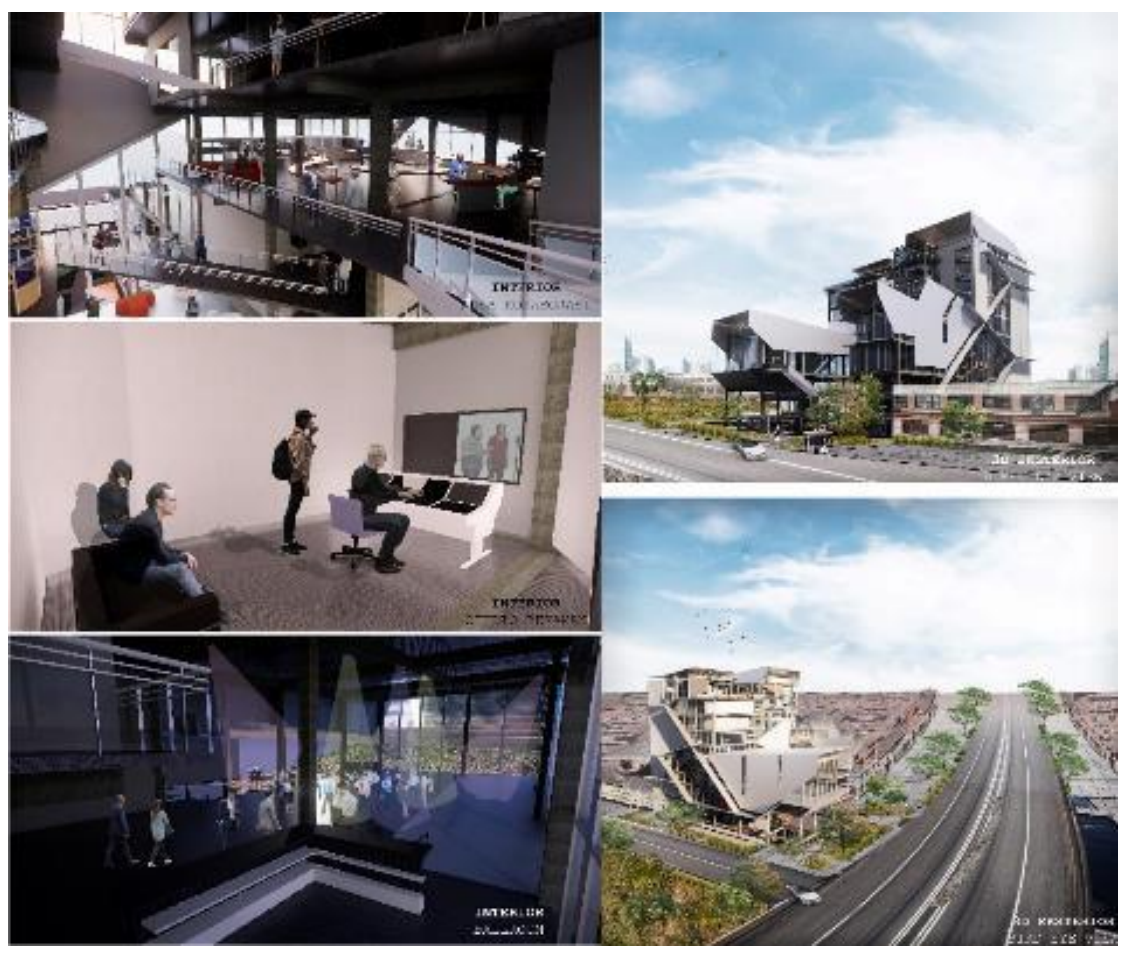

Gambar 14. Suasana Eksterior dan Interior Bangunan Sumber: Penulis, 2019 


\section{KESIMPULAN DAN SARAN}

\section{Kesimpulan}

Perkembangan tipologi kantor berkembang dengan acuan tipologi sebelumnya. Kantor kreatif di Tebet yang sesuai dengan kebutuhan milenial menciptakan suatu pengalaman ruang yang baru dengan memadukan fungsi dan program hiburan ke dalam program bekerja. Hal ini memberikan definisi baru terhadap kantor yang lebih memfasilitasi daripada menampung orang untuk bekerja.

\section{Saran}

Disarankan kepada peneliti dan perancang selanjutnya untuk dapat melanjutkan dan menyempurnakan penulisan dengan metode lainnya yang dapat menambahkan data serta studi terkait milenial dalam bekerja.

\section{REFERENSI}

Ali, H. dan Purwandi L. (2016). Indonesia 2020: The Urban Middle-Class Millenials. Jakarta: PT Alvara Strategi Indonesia

Antoniades, A. C. (1990). "Music and Architecture", Poetics of Architecture Theory of Design. New York: Van Nostrand Reinhold.

Aprilianti, D. F. (2018). Millennials, Generasi Tanggap Teknologi Namun Tak Punya Loyalitas. Pekerjaan Seperti Apa yang Mereka Cari. Retrieved February 11, 2019, from https://www.kalibrr.com/advice/2018/01/pekerjaan-yang-dicari-millennials

Blakke, M. (2014). The Resonant Human: The Science of How Tempo Affects Us. Retrieced February 11, 2019, from https://sonicscoop.com/2014/06/19/the-resonant-human-thescience-of-how-tempo-affects-us/

Darmajati, R. S. (1983). Istilah-istilah dunia pariwisata, Pradnya Paramita, Jakarta

Davies, M. A. (2000). Learning the beat goes on. Childhood Education, 76(3), 148-153.

Jaya, B. A. (2016). Tipologi Sarana Perkantoran: AR. 3131 Perkembangan Tipologi Arsitektur. Retrieved 10 February 10, 2019, from https://www.scribd.com/doc/301533798/TipologiSarana-Perkantoran

Liu, H. (2012). Distributed Workplace for Facebook. Inc: a new ofce typology for the 21st century workstyle. Retrieved February 10, 2019, from https://surface.syr.edu/architecture_tpreps

Purwantiasning, A. W. \& Djuha, A. M. (2016). Musik Dalam Dimensi Ruang Arsitektur. Republika Online: Jakarta

Satiadarma, M.P. (2002). Terapi Musik. Milenia Populer, Jakarta.

Tschumi, B., (2005). Event- Cities 3: Concept vs. Context vs. Content, MIT Press, Cambridge, Massachussetts

Tsukamoto, Y. (1965). Behaviorology: Atelier Bow - Wow. New York: Rizzou 